\title{
A Neoproterozoic flare-up magmatic event in Northeastern Brazil
}

\author{
VALDEREZ P. FERREIRA ${ }^{1}$, CHARLES H NEVES ${ }^{1}$, \\ THYEGO R SILVA ${ }^{2}$, MARIUCHA C LIMA ${ }^{2}$, ALCIDES N. \\ SIAL $^{1}$ AND ADEJARDO F SILVA FILHO ${ }^{1}$
}

${ }^{1}$ Federal University of Pernambuco

${ }^{2}$ Water and Climate Agency of Pernambuco

Presenting Author: valderez.ferreira@ufpe.br

The composite Santana do Ipanema batholith is made up several Cryogenian-Ediacaran granitic plutons in the Pernambuco-Alagoas Domain of the Borborema province, northeastern Brazil. The granitoids are characterized by the presence of biotite and calcic amphibole (and pyroxene in some plutons), are metaluminous to peraluminous I-type granites of the high-K calc-alkalic to shoshonitic series of rocks, part of the magnetite-series of granitoids, with characteristics of magnesian, Cordilleran-type rocks. They carry comagmatic microgranular mafic enclaves with evidence of magma mixing. Their chemical compositions overlap, and they exhibit enrichment in some incompatible and depletion in HFS elements, with variable initial ${ }^{87} \mathrm{Sr} /{ }^{86} \mathrm{Sr}$ ratios that range from 0.70511 to 0.71071 . The data indicate that the batholith is composed of several magma pulses emplaced in the Cryogenian-Ediacaran formed by amalgamations of many small magmatic additions by diking over 30 m.y., with no large crystallization age gap among the plutons. In spite of this, the plutons form two $\mathrm{Nd}$ isotopes distinct groups in such way that plutons older than $\geq 625$ Ma show slightly negative to slightly positive eNd values, while younger plutons have more negative ones, suggestive that the genesis of the oldest granite magmas involved larger contributions of mantle-derived material. The estimated magma supply rate for the construction of the batholith, together with two other batholiths in the Pernambuco-Alagoas Domain, suggests a flare up event in the main stage of the Brasiliano orogeny, probably triggered by repeated basaltic underplating stalled in the lower crust, in magmatic arc setting, during the convergence of the São Francisco craton and the Pernambuco-Alagoas block. 